\title{
Dietary patterns among nutrition students at a public university in Brazil
}

\author{
Patrón alimentario de estudiantes de \\ nutrición de una universidad pública de Brazil
}

\begin{abstract}
This cross-sectional study aimed to analyze the dietary patterns of 125 nutrition students in 2011, from public university in Bahia State, Brazil. The students answered a structured and validated questionnaire for this specific group that addressed socioeconomic and health aspects, family information, and food consumption. Dietary patterns were determined using factor analysis by principal components analysis. The mean age was 22.3 (SD: 3.75) years old. The majority (88\%) of students were female. In relation to the dietary patterns of the students, 4 groups were identified and these patterns explained $59.8 \%$ of the total dietary variability. The pattern number 1, entitled "Traditional", consisted of roots/tubers, legumes, dairy products, meat and eggs, fruit/natural juice and vegetables, and explained $21.53 \%$ of the variability of food consumption. Pattern 2, labeled "Exam Days" was made up of breads/cereals, sausages and artificial beverage accounted for $13.85 \%$ of the variability of food consumption. Pattern 3, entitled "End of Semester" was characterized predominantly by candy/sugar and snacks and represented $13.39 \%$ of the variability of food consumption. Pattern 4, labeled "Anxiety" which was made up of coffee/tea and fats, explained $11.08 \%$ of the variation of food consumption. It was observed that $38.1 \%$ of the students have inadequate food consumption because they are monotonous, and poor sources of fiber and vitamins.

Key words: Eating behavior, dietary habits, diets, university, nutrition.
\end{abstract}

\section{INTRODUCTION}

Entry to university brings new responsibilities to students in regards to food, housing and financial management (1). Within this context, the risk factors of an inappropriate lifestyle, represented by a sedentary lifestyle, psychosocial factors and the high demands of academia can contribute to the adoption of nutritionally unbalanced eating habits. Therefore, the risk of the development of chronic, non-communicable diseases increases $(2,3)$.

On the other hand, enrolling in the course of nutrition provides access to information on nutritionally balanced eating habits. Thus, it is assumed that the knowledge acquired by the students of this course can positively influence the dietary patterns. This is defined as a set or group of foods normally consumed by individuals or populations (4).

The identification of the eating patterns of the students is an important strategy for promoting balanced nutrition during the phase of graduation. However, there are still very
Marcos Pereira-Santos $(1,2)$

Jerusa da Mota Santana (2) Ana Caroline Neves de Carvalho (3)

Fernanda Freitas (3)

(1) Center of Biological Sciences and Health Federal University of Western Bahia, Barreiras, Bahia, Brazil (2) Institute of Public health, Federal University of Bahia, Salvador, Bahia, Brazil (3) Center for Health Sciences, Federal University of Recôncavo of Bahia, Santo Antônio de Jesus, Bahia, Brazil

Author for correspondence: Marcos Pereira-Santos Escola de Nutrição, Núcleo de Epidemiologia e Nutrição, Universidade Federal da Bahia, Rua Araújo Pinho, 32 Canela, Salvador-BA CEP:40110-150, Brazil. E-mail: pereira-santosm@bol.com.b

Este trabajo fue recibido el 21 de Julio de 2015 y aceptado para ser publicado el 30 de Octubre de 2015.

few studies that evaluate the dietary patterns of university students, because most of the work identified in the literature only assesses nutrient and energy intake (5). This approach can be considered reductionist by solely analyzing nutrients, and not the complex interaction between food and/or nutrients.

Thus, the dietary intake assessed by the dietary pattern analysis represents more reliably the eating habits of the population groups (5). From this perspective, this study aims to identify the dietary patterns of nutrition students at a public university in Brazil.

\section{METHODOLOGY}

Study design and population

The study consists of a cross-sectional study, conducted from April to June 2011, with a sample of 125 undergraduate nutrition students from a public university in the state of Bahia, Brazil. To calculate the sample, the lifestyles of 277 individuals who regularly attended the course at different entry 
periods (1st to 9th semesters) were considered, an appropriate frequency of consumption of fruits and vegetables among students estimated at $24.9 \%$ (6), with a margin of error of 5 $\%$ and a power of $90 \%$. Thus, to represent the course it would be necessary to interview 118 students. To compensate for possible losses, the final sample consisted of 125 individuals.

\section{Data collection}

Students were asked to answer a structured questionnaire, previously validated for the group under study, divided by the following items: socioeconomic, family information, dietary intake and health status and questionnaire of food intake frequency. This questionnaire was applied individually, in order to better understand the eating habits of the students of the nutrition course.

The food frequency questionnaire (FFQ), according to Willett (7), was used. It was simplified, and developed from the food pyramid which was adapted to the Brazilian population by Sichieri and Everhart (8) to investigate the food intake of students of nutrition. The FFQ was composed of 70 food items and the frequency of consumption was represented by 7 categories, namely: daily (once a day, twice or more times a day), weekly (once a week, two to four times a week), monthly (less than once a month, one to three times a month) and never. The changes in the volume and fractioning of the diet during the academic period were evaluated and compared with the intake over the weekends (3).

Prevalence was adopted to describe the categorical variables and for the continuous variables, mean and standard deviation were adopted. To analyze the income variable, the minimum wage in the period of data collection was considered, $R \$ 545.00$, and the anthropometric classification was performed by the calculation of the body mass index (BMI), calculated by weight $(\mathrm{kg}) /$ height $^{2}(\mathrm{~m})$, using the height and weight values provided by the participants. BMI was classified according to the cut-off point established by the World Health Organization (9).

In regards to the identification of dietary patterns, initially the transformation of frequencies of consumption to daily frequency was performed, as proposed by Coelho et al (2011) (10). Thus, the food value of 1 (one) was attributed when the food was consumed once a day. For consumption of more than once a day, the value of 1 was multiplied by the reported daily frequency. The information which contemplated the weekly and monthly intervals used the average interval of the frequency, divided by the period: weekly (7), and monthly (30).

Food groups according to the nutritional characteristics were defined. In this regard, 13 food groups were established (1) snacks; (2) sweets and sugars; (3) fat; (4) breads and cereals; (5) roots and tubers; (6) legumes; (7) dairy products; (8) meat and eggs; (9) sausages; (10) artificial beverages; (11) coffee and tea (12) fruit and natural juice (13) vegetables.

\section{Statistical analysis}

After the construction of the food groups, factor analysis (FA) was adopted for key components, in order to identify the dietary patterns of the students of Nutrition.

Prior to implementation of the factorial method, the adequacy of the applicability of this method to the data set was evaluated. For this, we used the Kaiser-Meyer-Olkin (KMO) test of adequacy and Bartlett's sphericity test. The value of KMO (0.77) and the Bartlett's test of sphericity $(p<0.001)$ suggest that the data is suitably applied to factorial analysis.

We used the percentage of commonality to evaluate the permanence of the food groups in the factor analysis. The commonality of the database ranged from 0.49 to 0.75 . These values were above the recommended minimum commonality 0.311 .

After the extraction of the dietary patterns, they were labeled according to the food groups present in each factor and the academic context of the student.

With respect to the sample size, it showed a ratio of 9.5 , considered appropriate due to the fact that the recommended ratio to compose the study sample should be between five to ten times the number of food items in the food frequency questionnaire (11).

The dietary patterns were extracted by a principal component analysis (PCA). After the extraction of the factors (dietary patterns), they were rotated in accordance with varimax rotation, in order to enhance the interpretability of each factor. The number of extracted factors that best represent the data set was defined by the graphic test Cattell or Scree plot, with accepted factors having eigenvalues above 1 . The selected food groups to compose each dietary pattern were those with factor loadings $\geq 0.4$.

The internal consistency of each factor was assessed using Cronbach's Alpha test and to evaluate the sample size, the relative number of individuals/food items was used. The Cronbach Alpha index showed an acceptable value of 0.74 , indicating homogeneity of the eating pattern. Finally, the labeled standards were based on the food groups which comprised each factor.

After the extraction of the dietary patterns, and after analyzing the factor loadings, they were labeled: Traditional Pattern, test day pattern, end of semester pattern and anxiety pattern. These labels took into account the composition of the food groups of each pattern and the moments of stress experienced by students in different periods of the semester. Thus, the traditional pattern includes foods that are part of the local food culture of the region, and are present in the food habits of the population, using socio-cultural and traditional characteristics (12).

The test day pattern was named as such due to it containing processed foods and high glycemic index foods, which are easy to be prepared, saving time to study for the exams of the semester.

The end of semester pattern was characterized by foods like sweets and snacks, foods associated with the reduced availability of time the student has for the preparation of food due to the workload of the end of the semester, as well as the absence of some main meals.

The anxiety pattern, characterized by coffee, teas and fats, reveal a pattern found in eager students who adopt a greater consumption of foods that contain caffeine to keep the body alert for performing academic activities.

The program Statistical Package for Social Sciences, version 17, was used for data analysis.

\section{Ethical issues}

With regard to the ethical aspects of the research that originated this study, they were evaluated and approved by the Research Ethics Committee, and all students signed the consent form free and willingly, with anonymity and information confidentiality guaranteed.

\section{RESULTS}

The main descriptive characteristics of the 125 graduates are presented in table 1. The average age of students was 22.3 
years $(S D=3.75)$, with most being under the age of $22(79 \%)$. Females (88\%) and mixed skin color (47.2\%) were predominant in the study population. It was observed that $12 \%$ of the respondents worked and $72 \%$ of the students had a total daily time spent at the University of 5 to 8 hours.

Most students reported as an income family support (68.8 $\%)$ and the others university scholarship (13.6\%) and work (9.6\%). In addition, $55.2 \%$ students mentioned that their parents had incomes of up to 4 minimum wages (table 1).

According to the analysis of the BMI, the 'healthy' status was predominant in $70.4 \%$ of the students (table 1), however, after entering university, the students reported a change in weight. It was observed that in periods of greater academic activity there was a downward trend in the volume of meals $(60.5 \%)$. On weekends the students increased the fractioning of the daily diet (56.5\%) and the size of the meal (45.2\%), as shown in the graph (figure 1).

In relation to the dietary patterns of the students, 4 groups were identified and these patterns explained $59.8 \%$ of the total dietary variability (table 2 ).

The food groups that composed the factors were those with a higher factorial load larger or equal to 0.4, with the greatest saturation being considered (table 2). From this perspective, the pattern number 1 , entitled "Traditional", consisted of roots/tubers, legumes, dairy products, meat and eggs, fruit/natural juice and vegetables, and explained 21.53 $\%$ of the variability of food consumption. Pattern 2, labeled "Exam Days" was made up of breads/cereals, sausages and artificial beverage accounted for $13.85 \%$ of the variability of food consumption. Pattern 3, entitled "End of Semester" was characterized predominantly by candy/sugar and snacks and represented $13.39 \%$ of the variability of food consumption. Pattern 4, labeled "Anxiety" which was made up of coffee/ tea and fats, explained $11.08 \%$ of the variation of food consumption.

The factorial scores of candy/sugar and fruit were high and the group of fats (butter and margarine) presented a low factorial score (table 2). It was observed that $38.1 \%$ of the variation in food consumption is represented by patterns of food consumption considered inappropriate (exam days, end of semester and anxiety).

\section{DISCUSSION}

This study permitted the identification of four patterns of food consumption among Nutrition students. Among them, three patterns of food consumption (patterns of Exam Days,

\section{TABLE 1}

Socio-demographic and anthropometric characteristics of students of Nutrition, Bahia, Brazil, 2011.

\begin{tabular}{|c|c|c|}
\hline Variables & $\mathrm{N}$ & $\%$ \\
\hline \multicolumn{3}{|l|}{ Sex } \\
\hline Male & 15 & 12,0 \\
\hline Female & 110 & 88,0 \\
\hline \multicolumn{3}{|l|}{ Age } \\
\hline$<22$ years & 79 & 63,2 \\
\hline$\geq 22$ years & 46 & 36,8 \\
\hline \multicolumn{3}{|l|}{ Skin colour } \\
\hline White & 32 & 25,6 \\
\hline Mixed & 59 & 47,2 \\
\hline Black & 34 & 27,2 \\
\hline \multicolumn{3}{|l|}{ Employment } \\
\hline Yes & 15 & 12,0 \\
\hline No & 110 & 88,0 \\
\hline \multicolumn{3}{|l|}{ Accomodation } \\
\hline Friends & 69 & 55,2 \\
\hline Family & 49 & 39,2 \\
\hline Alone & 7 & 5,6 \\
\hline \multicolumn{3}{|c|}{ Family income (minimum salaries) } \\
\hline$<1-4$ & 69 & 55,2 \\
\hline$>5$ & 35 & 28 \\
\hline Doesn't know & 21 & 16,8 \\
\hline \multicolumn{3}{|l|}{ Marital status } \\
\hline Single & 117 & 94,4 \\
\hline Married & 07 & 5,6 \\
\hline \multicolumn{3}{|l|}{$\mathrm{BMI}$} \\
\hline Underweight $(<18.5)$ & 19 & 15,2 \\
\hline Healthy $(18.5-24.9)$ & 88 & 70,4 \\
\hline Overweight $(25-29.9)$ & 13 & 10,4 \\
\hline Obese $(>30)$ & 2 & 1,6 \\
\hline \multicolumn{3}{|c|}{ Total daily hours spent at the university } \\
\hline $1-4$ & 51 & 40,8 \\
\hline $5-6$ & 36 & 28,8 \\
\hline $7-9$ & 38 & 30,4 \\
\hline
\end{tabular}


End of Semester and Anxiety) can be considered health risks to the university students because they are nutritionally inadequate, monotonous and low in terms of sources of fiber and nutrients necessary to maintain health.

The results of the dietary patterns identified among the students of this present study follows the trend of dietary patterns of university students in general, in which mainly the consumption of processed and industrialized foods, and high in content of simple carbohydrates, saturated fats, and the reduced consumption of dairy products, sources of fiber and micronutrients were observed (6,13-16). In addition, one must consider that the pattern of dietary consumption of students

\section{TABLE 2}

Distribution of the factorial loadings for the four components (Dietary Patterns) identified in the diets of students of Nutrition. Bahia, Brasil, 2011.

\begin{tabular}{lcccc}
\hline \multirow{2}{*}{ Foods/ Food groups } & \multicolumn{4}{c}{ Dietary patterns } \\
& Traditional & Exam days & End of Semester & Anxiety \\
Roots and tubors & 0,740 & - & - & - \\
Legumes & 0,602 & & - & - \\
Dairy products & 0,722 & - & - & - \\
Meats and eggs & 0,499 & - & - & - \\
Fruits & 0,833 & - & - & - \\
Vegetables & 0,749 & - & 0,607 & - \\
Snacks & - & - & 0,862 & 0,494 \\
Sweets and sugars & - & - & - & 0,695 \\
Fats & - & - & - & - \\
Coffee and tea & - & 0,639 & - & - \\
Breads and cereals & - & 0,766 & - & - \\
Artificial beverages & - & 0,715 & - & 1,4 \\
Sausages & - & 1,8 & 1,7 & $11,0 \%$ \\
Eigenvalues & 2,8 & $13,8 \%$ & $13,3 \%$ & $59,8 \%$ \\
\% explanation of the variance & $21,5 \%$ & $35,3 \%$ & $48,7 \%$ & 0,73 \\
\% accumulated variance & $21,5 \%$ & 0,71 & 0,73 & - \\
Cronbach's Alpha & 0,72 & & & - \\
\hline
\end{tabular}

\section{FIGURE 1}

Graph (\%) on the dietary behavior of students of Nutrition after entry into University, Bahia, Brazil, 2011.

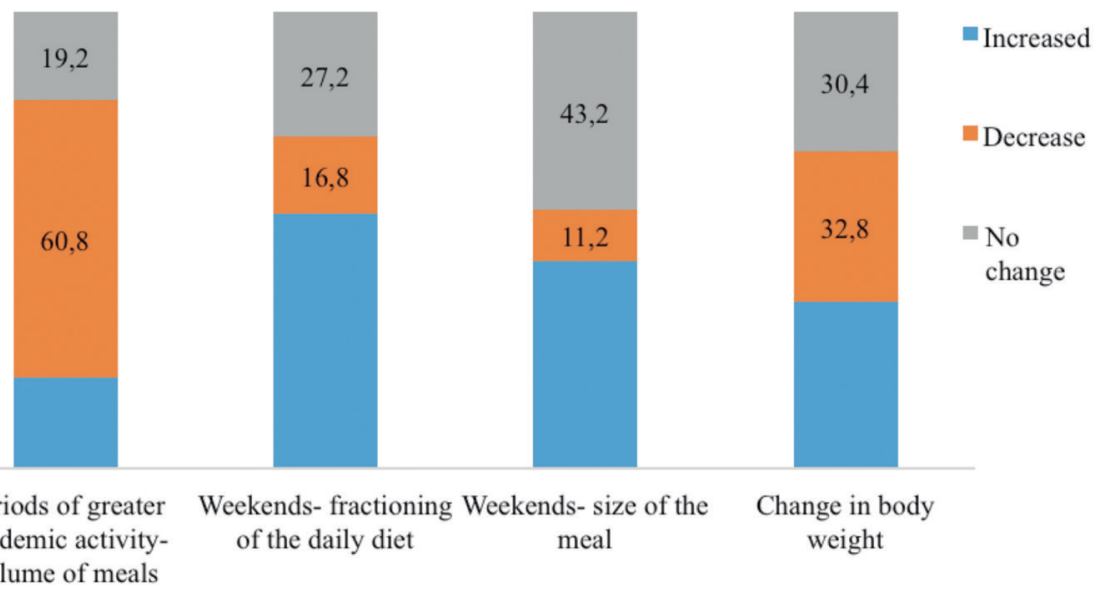


may be also influenced by income, food security and nutrition status, due to residing away from home, and the support and retention of policies aimed at students of higher education.

It can also be noted that these eating patterns, by being considered a risk, could be related to periods of greater academic activity; a condition that may have a negative impact on food choices. In this sense, it was observed that the students reported a reduction in the volume of meals in periods of greater academic activity. On the other hand, upon entering university, students tend to leave their family homes and build a new independent lifestyle, which may decrease the prevalence of healthy eating habits. This may contribute to the increased consumption of foods with a high caloric density and, consequently, increased weight gain after entry into university. Research on university students report important changes in dietary intake, especially the low intake of fruits and legumes $(17,18)$. This change in eating habits can be an influence of leaving the family environment, since the students who live in with family tend to consume more fruit and vegetable when compared to those who live away from their home and family (13). According to Papadaki (19), students living away from the family home reduce the weekly consumption of fresh vegetables and raw and cooked fruits, which is why, in the family environment, there is a greater availability of fruits and vegetables, which are preferably chosen over other foods $(20,21)$.

On the other hand, a trend towards the greater consumption of foods considered patterns of risk, has also been reported in epidemiological research of the Brazilian population $(21,22)$, which may indicate that the dietary profile of the students of this research may reflect the changes in the dietary patterns and nutrition of the Brazilian population over the last two decades.

In this study, it was observed that during the weekend there was a change in the dietary pattern, with an increase in the consumption of foods with better nutritional value and a higher fractioning of meals. Thus, it is assumed that knowledge of food and nutrition are employed positively at opportune moments, mainly in those associated with the family context.

One result of the study (3) reveals that students changed their food consumption at weekends when compared to consumption during the week. This dietary change is mainly related to greater inclusion of breakfast, improved quality of intake with the increased consumption of fruits, and the inclusion of lighter foods (3).

The elevated consumption of sweets and fatty foods and lower intake of fruits and vegetables in periods of greater academic activity is proportional to the level of stress of the students $(3,23)$. This trend was recorded in a study of students of an Australian university, in which levels of mild and moderate stress contributed to an increase in processed foods, meats and a decreased consumption of vegetables and fruits (24).

In this regard, individual variability is noted as an important factor in this process because there are individuals whose stress and anxiety factors have a negative impact on their dietary intake, sometimes proportioning an increased consumption at exacerbated levels, while sometimes reducing consumption or balancing it.

In addition, it was observed that only one dietary pattern (the traditional pattern) was considered protective, and was identified among students and this represents minimally the feeding habits of the students, since the foods that make up this pattern were consumed at a low frequency. The reduction in the consumption of foods of this dietary pattern, to the de- triment of other extracted patterns is worrying, since they are sources of complex carbohydrates, protein of high biological value, fiber and vitamins and minerals. Thus, it is the pattern that is closest to the recommendations issued by national and international bodies to promote a healthy diet $(21,22)$.

It is noteworthy that the food consumption patterns extracted for specific populations are not always reproducible and comparable to other populations with different eating habits (25). This lack of comparability may be related to the wide use of methods that assess dietary intake, diet questionnaires containing peculiar food lists for a certain region, different nomenclatures and cultural differences of each population (10). However, despite this difficult comparison, there are no studies with the same proposal of this research, which makes it relevant.

This study highlights the importance of the characterization of dietary patterns at graduation level education, since the determinants of diseases do not arise from lack of nutrients, but through the combined way that they interact with aspects of the lifestyle of the individual (26). In this sense, three patterns of food consumption were identified that, when associated with an improper lifestyle, characterized by high academic demands, and physical inactivity can be considered risk factors for the onset of chronic diseases in adulthood or in later life. Therefore, the university can promote activities in favor of a healthy lifestyle and healthy diet, in an aim to contribute to the prevention of diseases and provide a better quality of life for students.

\section{RESUMEN}

Estudio transversal que tuvo por objetivo identificar los patrones alimentarios de 125 estudiantes de nutrición de una universidad pública del estado de Bahía, Brasil en el 2011. Los estudiantes respondieron un cuestionario validado para frecuencia de consumo de alimentos. Se empleo análisis factoriales para los componentes principales con el fin de identificar los principales patrones alimentarios de esos estudiantes. La media de edad fue de 22,3 años ( $D P=3,75)$. En relación a los patrones alimentarios fueron identificados cuatro patrones de consumo alimentario que explican $59,8 \%$ de la variabilidad total de la dieta. El patrón 1, nombrado "tradicional", compuesto por tubérculos, leguminosas, derivados lácteos, carnes e huevos, frutas en jugo/natural y hortalizas explicó 21,53\% de la variabilidad; el patrón 2, nombrado "Días de prueba" integrado por panes/cereales, bebidas artificiales y embutidos respondió 13,85\% de la variabilidad; el patrón 3, "Final de Semestre" fueron predominantes los dulces/azúcar y aperitivos este representó 13,39\% de la variabilidad del consumo de alimentos: y el patrón 4 "Ansiedad" compuesto por café/te y grasas explicó $11,08 \%$ de la variación. Se observó que 38,1\% de la variación del consumo de alimentos es representado por patrones de consumo de alimentos considerados inadecuados, pues son monótonos y pobres en fibra y vitaminas.

Palabras clave: Comportamiento alimentario, hábitos dietéticos, dieta, universidad, nutrición.

\section{REFERENCES}

1. Petribú MMV, Cabral PC, Arruda IKG. Nutritional status, food consumption and cardiovascular risk: a study on university students. Rev Nutr, 2009; 22(6):837-46.

2. Monteiro MRP. Andrade MLO, Zanirati VF, Silva RR. Eating habits and intake of female students of Nutrition and Nursing in a Brazilian public university. Rev APS, 2009;12 (3): 271-7. 
3. Vieira VCR, Priore SE, Ribeiro SMR, Franceschini SCC, Almeida LP. Socioeconomic, nutritional and health profile of adolescents recently admitted to a Brazilian public university. Rev Nutr, 2002; 15(3):273-82.

4. Garcia RWD. The food, the diet, the taste. Changes in the urban food culture. Säo Paulo; 1999 p 312.

5. Matos SMA, Barreto $M L$, Rodrigues $L C$, Oliveira $V A$, Oliveira LPM, D'Innocenzo $S$, et al. Dietary patterns of children under five years of age living in the State capital and other counties of Bahia State, Brazil, 1996 and 19992000. Cad Saúde Pública, 2014; 30(1):44-54.

6. Marcondelli P, Costa THM, Schmitz BAS. Physical activity level and food intake habits of university students from 3 to 5 semester in the health area. Rev Nutr, 2008; 21(1): 39-47.

7. Willet WC. Reproducibility and valitidy of food-frequency questionaries, In: Willet WC. Nutricional epidemiology. 2 ed. Oxford: University Press, 1998, p. 101-47.

8. Sichieri $R$, Everhart JE. Validity of a Brazilian food frequency questionnaire against dietary recalls and estimated energy intake. Nutr Res. 1998; 18(10):1649-59.

9. WHO Expert Committee on Physical Status: the use and interpretation of Anthropometry Physical status: the use and interpretation of anthropometry: Report of a WHO expert committee. WHO (Technical report series; 854) World Health Organization, 1995.

10. Coelho NLP, CUNHA DB, Esteves APP, Lacerda EMA, Theme Filha MM. Padrão de consumo alimentar gestacional e peso ao nascer. Rev Saúde Pública 2015; 49:62.

11. Hair JF. Análise Multivariada de Dados. Porto Alegre: Artmed, 2005.

12. Santana JM, Queiroz VAO, Brito SM, Santos DB, Assis AMO. Food consumption patterns during pregnancy: a longitudinal study in a region of the North East of Brazil. Nutr Hosp. 2015;32(1):130-8

13. De Piero A, Bassett $N$, Rossi A, Sammán N. Trends in food consumption of university students. Nutr Hosp. 2015 Apr 1;31(4):1824-31. doi:10.3305/nh.2015.31.4.8361

14. El Ansari W, Stock C, Mikolajczyk RT. Relationships between food consumption and living arrangements among university students in four European countries - a cross-sectional study. Nutr J. 2012 Apr 24;11:28. doi: 10.1186/1475-2891-11-28.

15. Espinoza OL, Rodríguez RF, Gálvez CJ, MacMillan KN. Hábitos de alimentación y actividad física en estudiantes universitarios. Rev Chil Nutr. 2011; 38( 4 ): 458-65.

16. Durán AS, Castillo AM, Vio del RF. Diferencias en la calidad de vida de estudiantes universitarios de diferente año de ingreso del campus Antumapu. Rev. chil. nutr. [Internet]. 2009 Sep [citado 2015 Oct 31] ; 36( 3 ): 200-9.

17. Lee RL, Loke AJ: Health-promoting behaviors and psychosocial well-being of university students in Hong Kong. Public Health Nurs 2005, 22:209-20.

18. Skemiene $L$, Ustinaviciene $R$, Piesine $L$, Radisauskas $R$ : Peculiarities of medical students' nutrition.Medicina (Kaunas) 2007, 43:145-52.

19. Baranowski T, Cullen KW, Baranowski J: Psychosocial correlates of dietary intake: advancing dietary intervention. Annu Rev Nutr 1999, 19:17-40.

20. Papadaki A, Hondros G, A Scott J, Kapsokefalou M: Eating habits of university students living at, or away from home in Greece. Appetite 2007, 49:169-76.

21. Brasil. Instituto Brasileiro de Geografia e Estatística. Pesquisa de Orçamentos Familiares 2008-2009: análise do consumo alimentar pessoal no Brasil. Rio de Janeiro; 2011.

22. Brasil. Instituto Brasileiro de Geografia e Estatística. Pesquisa de orçamentos familiares 2002-2003: análise da disponibilidade domiciliar de alimentos e do estado nutricional no Brasil. Rio de Janeiro; 2010.

23. Unusan, N. Linkage between stress and fruit and vegetable intake among university students: an empirical analysis on Turkish students. Nutr Res. 2006 ; 26 : 385-90

24. Papier $K$, Ahmed $F$, Lee $P$, Wiseman J. Stress and dietary behaviour among first-year university students in Australia: sex diferences. Nutrition. 2015; 31(2):324-30. doi: 10.1016/j.nut.2014.08.004.

25. Jacques PF, Tucker $K L$. Are dietary patterns usefull for understanding the role of diet in chronic disease? Am J Clin Nutr. 2001; 73:1-2.

26. Sichieri R, Castro JFG, Moura AS. Factors associated with dietary patterns in the urban Brazilian population. Cad Saúde Pública. 2003; 19(Supl.1): S47-S53. 